\title{
ASPECTOS GERAIS DO PERCURSO PROCESSUAL CIVIL, E A APLICABILIDADE DO PARCELAMENTO NAS EXECUÇÕES DE TÍTULOS JUDICIAIS
}

\author{
Juliana Gramacho Bomfim* \\ Professora Mestra Daniela Pozza Batista**
}

\section{RESUMO}

O tema execução, de modo geral, constantemente engloba alguma polêmica, debate ou discussão, seja porque muitos devedores escondem seus bens do Judiciário para não cumprir com a obrigação que lhe são impostas, entre outros aspectos. Porém, não será essa temática aqui abordada, e sim, o mecanismo do parcelamento quando em sede de cumprimento de sentença, tal mecanismo é assiduamente utilizado em compras e venda e renegociações de dívidas, fora da esfera do Judiciário. E em sede de cumprimento de sentença? Poderá ocorrer? Será benéfico e condizente com os princípios processuais? Para a referida análise, faz-se necessário a compreensão desde o início do Processo Civil para abordar o procedimento comum até o cumprimento de sentença e o procedimento da execução autônoma em seus aspectos gerais, pois ainda que seja um tema muito amplo, o artigo tem como objetivo a compreensão de todos acerca da análise, não somente os estudiosos do direito. Partindo desse pressuposto, teremos um respaldo razoável a fim de compreender os caminhos levarem a concepções distintas, a respeito da temática, e, então, concluir que parcelar a mencionada dívida no Judiciário não é um ato injusto que vai atribuir mais tempo à satisfação da obrigação, a referida prática está mais para uma técnica respaldada em princípios processuais civis, viabilizando, por exemplo, um processo mais célere e eficaz ao credor e ao devedor. Importante frisar que o presente artigo não tem o intuito de interceder a favor do devedor, mas sim, de demonstrar que nem sempre a doutrina e a jurisprudência minoritária são infundadas ou não merecem apreciação, tendo em vista que a formação de uma convicção em relação a qualquer temática demanda pesquisa, análise crítica e compreensão do assunto desde sua origem.

Palavras-chave: Processo Civil. Procedimento comum. Execução Autônoma. Parcelamento. Artigo 916.

* Bacharel em direito pela Universidade Metodista de São Paulo. Endereço eletrônico: juliana.gramacho@hotmail.com.

** Mestra em Direitos Difusos e Coletivos pela Universidade Metropolitana de Santos - UNIMES. Especialista em Direito Processual pela Universidade Paulista - UNIP. Advogada. Professora Universitária e Coordenadora do Escritório de Assistência Judiciária. 


\section{GENERAL ASPECTS OF THE CIVIL PROCEDURAL COURSE, AND THE APPLICABILITY OF THE INSTALLMENT PLAN FOR THE EXECUTION OF COURT ORDERS}

\section{ABSTRACT}

The issue of execution, in general, constantly encompasses some controversy, debate or discussion, because many debtors hide their assets from the Judiciary in order not to comply with the obligation imposed on them, among other aspects. However, this theme will not be debated here, instead, it will be the installment payment mechanism when in compliance whit judgment, such method is used in purchases and sales and debt renegotiations, outside the Judiciary. What about sentence compliance? Could it happen? Will it be beneficial and consistent with procedural principles? For this analysis, it is necessary to understand the beginning of the Civil Procedure to see the common procedure until the sentence is fulfilled and the autonomous execution procedure in its general aspects, because although it is a very broad topic, this article aims the understanding of all regarding the analysis, not only the studies of the law. Based on this assumption, we will have a reasonable support in order to understand the paths leading to different conceptions, about the theme, and then, conclude that splitting the mentioned debt in the Judiciary is not an unfair act that will take more time to finish the obligation, this practice is more like a technique supported by civil procedural principles, enabling, for example, a faster and more efficient process for the creditor and the debtor. It is important to emphasize that the present article does not intend to intercede in favor of the debtor, but rather to demonstrate that minority doctrine and jurisprudence are not always unfounded or do not deserve appreciation, considering that the formation of a conviction about any theme that demands research, critical analysis and also understanding of the subject from its origin.

Keywords: Civil Procedure. Common procedure. Autonomous Execution. Installment. Article 916.

\section{INTRODUÇÃO}

O propósito do presente artigo é examinar o processo civil, em seus aspectos gerais, desde seu início até a fase executória, possibilitando, assim, a compreensão do percurso processual civil, e, também, a percepção acerca do mecanismo de parcelamento da dívida exequenda, disposto no artigo 916 do Código de Processo Civil.

Portanto, verifica-se aqui, um exame global do processo de procedimento comum que objetiva formar um resultado (sentença) a fim de estabelecer o cumprimento da obrigação em questão e, examina-se a ação de execução autônoma, que, apesar de ser constituída de forma distinta, também forma um resultado que objetiva o cumprimento da obrigação no Judiciário.

Ocorre que o Código de Processo Civil estabelece a ambas as ações, ordinária ou executória autônoma, as mesmas medidas coercitivas de cumprimento da obrigação, entretanto, confere o oportuno parcelamento da dívida exequenda, somente as ações de execução autônomas. 
A proibição do pagamento em parcelas das dívidas oriundas do cumprimento de sentença divide opiniões de juristas, que questionam se o legislador agiu por bem ou por mal quando estabeleceu a referida proibição.

Diante disso é que se realiza a presente análise dos entendimentos divergentes entre a doutrina e a jurisprudência a respeito da temática, permitindo, finalmente, que se entenda qual dos posicionamentos está em maior coerência com os princípios que norteiam o processo civil.

\section{PROCESSO CIVIL}

A palavra processo, significa "Ação contínua e prolongada, que expressa continuidade na realização de determinada atividade" (PROCESSO, In: DICIO, 2018) e não é diferente no processo judicial, que é constituído por uma sequência de ações que são direcionadas através do ordenamento legal.

Esta relação processual jurídica poderá estabelecer-se quando ocorrido algum conflito de interesse nas relações sociais entre duas partes; explana José Eduardo Carreira Alvim (2018, p. 30) “o conflito de interesses é uma lide, enquanto uma das pessoas formula contra a outra uma pretensão, e esta outra oferece resistência."

Vale salientar que a concepção de ideia do que é uma lide, aqui explanada, é de fato sociológica:

O conceito de lide é controvertido, entendendo alguns que não se trata de um conceito essencialmente processual, porque todo processo pressupõe uma lide, mas nem toda lide desemboca, necessariamente, num processo; pelo que o conceito seria mais sociológico do que jurídico (ALVIM, 2018, p. 30).

Pois bem, a fim de solucionar a lide, ou seja, para que se constitua uma ação judicial, é necessário que se faça a provocação do Estado-Juiz, este é responsável por instruir e julgar procedente, ou não, o direito que será pleiteado na demanda judicial.

Esta provocação diz respeito a acionar a máquina de Jurisdição, isso porque ela é inerte, ou seja, não é possível que o Estado-Juiz atue por direito de outrem, sem que seja impulsionado a isto, como corrobora a doutrina: "Princípio da inércia - Segundo este princípio, não pode haver "jurisdição sem ação", pois a jurisdição depende de provocação do interessado no seu exercício, não sendo, de regra, automovimentada" (ALVIM, 2018, p.125).

Outro princípio basilar, o qual garante que podemos buscar a solução de uma lide por meio do Judiciário é o princípio do acesso à justiça, este veda qualquer restrição que impeça o indivíduo de acionar o Judiciário e está previsto na Constituição Federal, no artigo $5^{\circ}$, inciso XXXV in verbis:

Art. 5. [...]

XXXV - a lei não excluirá da apreciação do Poder Judiciário lesão ou ameaça a direito. (BRASIL,1988). 
A garantia de acesso à justiça ainda é prevista no artigo $3^{a}$ da lei $n^{\circ} 13.105 / 2015$, ou seja, no Código de Processo Civil, e assegura que:

Art. 3. Não se excluirá da apreciação jurisdicional ameaça ou lesão a direito." (BRASIL, 2015).

Assim, fica evidente a atuação do Judiciário enquanto garantidor da paz social, pois é por meio deste que se busca a solução de conflitos, os quais não foram dirimidos na esfera extrajudicial.

Não obstante, as vias extrajudiciais também colocam fim às lides, portanto, pode-se afirmar que o processo é a via adequada para resolver as lides que aparentam não haver solução e dessa maneira é necessário que o Judiciário analise o conflito em conformidade com o direito material, este, nas palavras de Theodoro Júnior $(2019$, p. 47) "cuida de estabelecer as normas que regulam as relações jurídicas entre as pessoas".

Importante destacar que o direito material se difere do ato de acionar a máquina do Judiciário, assim como explica o professor Montenegro Filho (2018, p. 42) "o direito de ação não garante, necessariamente, o reconhecimento do direito material que teria sido violado ou que se encontra em vias de ser. $\mathrm{O}$ direito material e o direito de ação são distintos e autônomos".

Percebe-se daí que o processo surge a partir do momento em que exista a violação, ou, ao menos a ameaça desta, de direito material, sendo tutelado o acesso à Justiça:

Na ordem global, enraizada sobretudo nas bases constitucionais, há um dever de tutela, que é acesso amplo e de caráter cívico, que vem a ser a garantia fundamental de que nenhum direito subjetivo violado ou ameaçado ficará privado do acesso à tutela da Justiça (CF, art. 5, XXXV) (THEODORO JÚNIOR, 2019, p. 50).

Compreende-se assim que a via processual é garantidora dos direitos materiais, e, segundo José Eduardo Carreira Alvim (2018, p. 59), “o direito processual é hoje uma disciplina autônoma da ciência do direito, fruto da grande evolução por que passou na segunda metade do século XIX".

Essa disciplina normatiza a sequência de atos inerentes a um processo, por meio da jurisdição, a qual é o poder que o Estado exerce de ministrar a justiça em conjunto com os princípios estabelecidos em nossa Constituição Federal e em cada ramo do direito.

Entre os vários princípios que mantêm o direito processual, temos alguns basilares, como, a exemplificar, o devido processo legal, do contraditório e ampla defesa e da razoável duração do processo.

Destaca-se devido processo legal, sendo imprescindível em todo e qualquer processo, pois preceitua que o processo judicial deve seguir todas as etapas previstas em lei além de sustentar os demais princípios (ALVIM, 2018). Conforme previsto no artigo $5^{\circ}$, LIV da Constituição Federal, sem este é impossível que haja privação da liberdade ou dos bens de alguém. 
O princípio do contraditório, também conhecido pela expressão latina audiatur et altera pars e a ampla defesa encontra-se no artigo $5^{\circ}$, inciso LV. Esse princípio existe uma vez que, segundo José Eduardo Carreira Alvim (2018, p. 264) "ao ataque deve ser assegurada a defesa, não podendo a pessoa ser condenada sem que tenha tido a oportunidade de se defender".

Outro princípio relevante ao estudo, é o da razoável duração do processo, que assegura um percurso célere. O inciso LXXVII do artigo $5^{\circ}$ da Constituição Federal preceitua:

Art. 5. [...]

LXXVII - a todos, no âmbito judicial e administrativo, são assegurados a razoável duração do processo e os meios que garantam a celeridade de sua tramitação (BRASIL, 1988).

O processo civil, propriamente dito, é um ramo do direito público que trata das normas e princípios que dispõem sobre a ação e a jurisdição e o processo no âmbito civil, ou seja, é o regimento processual diante à matéria civil, nesse sentido, e, de acordo com Ana Paula Zanin (2019, p. [1]) "o direito civil é o direito do cidadão. É matéria abrangente e disciplina direitos e deveres das nossas relações, sejam com pessoas ou coisas."

A Lei $\mathrm{n}^{\mathrm{0}} 13.105$ de 2015, mais conhecida como Código de Processo Civil, se divide em parte geral, com cinco livros, parte especial, com três livros, e o livro complementar que traz as disposições finais e transitórias.

Logo no início do Código de Processo Civil, em seu artigo dezessete, vincula a ação civil à duas condições: a legitimidade e o interesse, considerando que, de acordo com Carlos Eduardo Ferraz de Mattos Barroso (2018, p. 33) "legítimos para figurar em uma demanda judicial são os titulares dos interesses em conflito." Já o interesse está atrelado à necessidade de trazer a lide ao Judiciário, também nas palavras de Barroso (2018, p. 34) "como necessidade, compete ao autor demonstrar que sem a interferência do Judiciário sua pretensão corre o risco de não ser satisfeita espontaneamente pelo réu."

Além da Constituição Federal, fonte de qualquer ramo do direito, e o Código de Processo Civil, deve-se considerar os costumes ${ }^{1}$, as doutrinas ${ }^{2}$ e as jurisprudências ${ }^{3}$ como fontes abstratas que cooperam para solucionar os entraves que possam surgir no Judiciário. Encontra-se nestas fontes as soluções judiciárias não encontradas na lei:

Não obstante, não raros são os problemas que surgem no curso dos processos que não encontram solução direta na lei, mas que o juiz tem de resolver. Daí o recurso obrigatório aos costumes judiciais, à doutrina e à

1 Conjunto das formas de pensar e de se portar identificadas numa pessoa ou sociedade: costumes brasileiros; família de falsos costumes;

2 Reunião dos fundamentos e/ ou ideias que, por serem essenciais, devem ser ensinadas;

3 Reunião das decisões tomadas num tribunal no âmbito do direito: a jurisprudência existe para suprir deficiências legais. Fonte? 
jurisprudência como remédios adequados à superação de tais impasses. (THEODORO JÚNIOR, 2019, p. 79).

O ramo processual civil dispõe de princípios próprios, nas palavras de Theodoro Júnior (2019 p. 60) “O direito processual se firmou como ciência autônoma no campo da dogmática jurídica por ter objeto e princípios próprios que não se confundem com o objeto e princípios das demais ciências do direito."

Logo no começo do $5^{\circ}$ Código Processual Civil verifica-se, mais precisamente no artigo $5^{\circ}$, que aqueles os quais atuarem no processo devem agir de boa-fé, ou seja, comportar-se de forma sincera, honesta, de modo justo e leal, inclusive os servidores públicos que movem a máquina do Judiciário. Dessa maneira:

\footnotetext{
A boa-fé deve nortear não apenas os negócios jurídicos, como também o comportamento das partes e de todos os que participem do processo, incluindo terceiros, auxiliares da justiça, magistrados, membros da Defensoria Pública e do Ministério Público, pessoas jurídicas de direito público e de direito privado. (MONTENEGRO FILHO, 2018, p. 43)
}

Assim também funciona o princípio cooperação, vide artigo $6^{\circ}$ do Código de Processo Civil, todos devem agir para que o desfecho processual seja justo e efetivo em tempo razoável.

O já pontuado princípio da razoável duração do processo é reforçado no artigo $4^{\circ}$ do Código de Processo Civil, salientando a lide solucionada de forma satisfativa.

Neste mesmo espírito, a fim de que o processo tenha um andamento mais célere e acessível, o Código Processual Civil rege a tramitação dos atos processuais na via eletrônica, estes apresentam regulamentação própria fora do Código, um meio contemporâneo que evidentemente atribui mais celeridade processual, apontado por Theodoro Júnior et al. (2015, p. 126) "nesses termos, o chamado "processo eletrônico" deve ser visto como uma ferramenta facilitadora da prática dos atos processuais [...]".

Importante destacar que, embora seja necessário a efetivação de todas as normas jurídicas e solenidades existentes no processo civil, os artigos 188 e 277 do diploma legal, remetem ao princípio da instrumentalidade das formas e este preceitua que o mais importante de um ato processual não é sua forma ou sua peculiaridade, e sim, perceber se este ato cumpriu sua função, quando um ato exigir forma determinada será expresso em lei.

Não obstante achar-se muitos outros princípios importantes no caminho processual, é possível compreender que esses e os regimentos legais do Processo Civil são agregados uns aos outros e assim norteiam a ação civil, que é composta por fases distintas e claramente segregadas pelo Código de Processo Civil, em consonância do procedimento apontado pela lei, podendo ser comum ou especial.

É notório também que a dinâmica processual civil avança conforme os prazos que são atribuídos para cada ato dentro do processo. A contagem dos prazos em dias considera somente os úteis, sejam estes estabelecidos pela lei ou pelo juiz, vide artigo 219. 
Pois bem, uma vez que as concepções triviais do processo civil foram abordadas, é possível compreender acerca dos procedimentos processuais. A distinção entre procedimentos comuns e especiais é feita por meio de exclusão, assim dispõem o artigo 328, deste modo, caso não haja previsão legal específica para determinada causa ser processada por do rito especial, esta será processada por do rito comum.

O processo de conhecimento comum é considerado por Theodoro Júnior (2019, p. 1087) "o mais completo e o mais apto à perfeita realização do processo de conhecimento, pela amplitude com que permite às partes e ao juiz pesquisar a verdade real e encontrar a justa composição da lide", este percorre quatro fases, a postulatória, a de saneamento, a instrutória, a decisória e o cumprimento da sentença. Nota-se que as fases se mostraram separadas, pois cada uma é própria a uma atividade processual, entretanto, por vezes elas podem se interpenetrar. (THEODORO JÚNIOR, 2019).

A primeira fase é nomeada como postulatória. A palavra postular significa solicitar, provando a solicitação (POSTULAR, In.: Dicio, 2020). Essa fase processual é iniciada por meio de uma petição ${ }^{4}$ que dá início ao processo jurídico, cujos requisitos intrínsecos para formulação estão no artigo 319 do Código, ora sintetizado.

Na petição inicial o autor deverá indicar para qual juízo está remetendo a ação; qualificar as partes com informações basilares como nome e sobrenome, o estado civil, a existência de união estável, a profissão, o número de inscrição no Cadastro de Pessoas Físicas ou no Cadastro Nacional da Pessoa Jurídica etc.; expor os fatos e fundamentos jurídicos do pedido, realizar os pedidos com suas especificações; indicar o valor da causa, vide artigo 292 do Código; indicar as provas que pretende produzir; registrar se há interesse na realização de audiência de conciliação.

Os documentos considerados indispensáveis à propositura da ação deverão instruir a petição inicial nos termos do artigo 320, considerado este, um requisito extrínseco.

Remetida para o juízo a petição inicial, o juiz irá verificar se todos os requisitos legais foram preenchidos, havendo algo a ser emendado será apontado por ele, e concede-se o prazo de 15 (quinze) dias para a emenda processual, conforme preconiza o artigo 321 do Código. Este momento é crucial no processo, pois caso o pedido inicial não seja corrigido o pedido inicial será indeferido e o mérito não revolvido, como preceitua o artigo 485.

Havendo êxito no preenchimento de todos os requisitos legais, é preciso que a parte adversária do processo, denominada réu, tome ciência de que o litígio chegou ao Judiciário por meio da citação, integrando a relação processual conforme estabelece o artigo 238, e, assim tenha a oportunidade de se defender.

Nesse momento a relação processual é estabelecida entre esses três componentes, sendo que, como observado por Alvim (2018, p. 230), "não pode haver processo sem a presença de autor, juiz e réu, porque, segundo a concepção dominante, a relação jurídica processual é um vínculo de, no mínimo, três sujeitos: autor, juiz e réu."

4 Requerimento; pedido efetuado de modo escrito. 
Uma vez estabelecida a mencionada relação processual de acordo com o artigo 334, o juiz designará audiência de conciliação ou de mediação, como o próprio nome diz, nessa oportunidade será proposto às partes realizarem uma conciliação na qual ambas estejam satisfeitas. Verifica-se que esta não será realizada se Autor e Réu manifestarem expressamente desinteresse, na forma do parágrafo $5^{\circ}$ do artigo 334. Há casos em que não se admite a autocomposição, assim estabelece parágrafo $4^{\circ}$, incisos I e II do artigo em comento.

A de audiência no Judiciário, de acordo com Theodoro Júnior (2019, p. 1223) "é o ato processual solene realizado na sede do juízo que se presta para o juiz colher a prova oral e ouvir pessoalmente as partes e seus procuradores."

Ademais, não havendo autocomposição, inicia-se o prazo para o réu oferecer a contestação, em que pode-se alegar:

Art. 336. [...] toda a matéria de defesa, expondo as razões de fato e de direito com que impugna o pedido do autor e especificando as provas que pretende produzir (BRASIL, 2015).

Sempre é necessário observar o preenchimento de requisitos que a lei estipula, e mais que isso, verificar se não há nenhum desvio que caracterize irregularidades processuais. Para tanto, a próxima etapa no processo, intitulada saneadora. Tomar providências saneadoras significa usar de "medidas que visam o estabelecimento de princípios éticos ou eliminar irregularidades" (SANEAMENTO, In.: Dicio, 2020).

Esta responsabilidade de suprir as irregularidades processuais é atribuída ao magistrado nos termos do artigo 139, inciso IX que se encontra no Título IV, Capítulo I do livro processual civil. Os vícios de que o referido artigo dispõe são aqueles atos no processo que não observam os pressupostos ou requisitos estipulados para praticá-los, tais vícios podem ser sanáveis, como quando o juiz manda emendar a petição inicial ou insanáveis que caracterizam atos nulos, considerando os artigos 276 a 283 do Código de Processo Civil (BRASIL, 2015).

Em verdade, o saneamento processual acontece desde o recebimento da petição inicial, verifica-se no Capítulo IX do Código de Processo Civil as providências preliminares e do saneamento que deve ser realizado de forma preliminar, pois, segundo Theodoro Júnior (2019, p. 1088) “com isso, procura-se chegar à instrução, sem correr o risco de estar o processo imprestável para a obtenção de um julgamento de mérito".

Verifica-se ainda que o processo pode ser julgado por meio de uma decisão saneadora, até mesmo de forma parcial, nas hipóteses em que o diploma legal no artigo 355.

Resta comprovado que a etapa saneadora do processo é de suma importância para o prosseguimento ao cumprimento da função jurisdicional de forma saudável, livre de vícios e irregularidades que podem inclusive prejudicar o direito de outrem.

Em seguida, o processo passará pela instrução. Este é o momento processual que, consoante Alvim (2018, p. 330) “permite às partes fornecer ao juiz os ele- 
mentos necessários ao esclarecimento dos fatos em que se funda a pretensão ou a defesa, pois o juiz julga com base em fatos provados".

Um dos Capítulos mais extensos do livro do Código Processual Civil é o XII o qual trata de regulamentar as provas no decorrer do processo. Há de se observar que algumas provas, como o depoimento pessoal, o qual é o requerimento que uma parte faz para interrogar a outra ou a prova testemunhal ${ }^{5}$ são feitas por meio de oitivas ${ }^{6}$ (BRASIL, 2015), realizadas em juízo por meio de uma audiência de instrução e julgamento.

O encerramento da fase instrutória se dá com a finalização da produção de todas as provas pertinentes com o intuito de mostrarem ao magistrado uma direção para que decida o caso e coloque fim à lide.

Prosseguindo para a etapa na qual o juiz irá proferir sua decisão, sentenciando o mérito da lide, sabe-se que a sentença coloca fim à fase cognitiva do procedimento comum, o juiz faz seu pronunciamento fundamentado nos artigos 485 e 487 do CPC (ALVIM, 2018).

A formação da sentença inclui o relatório que sintetiza as informações das partes e os andamentos processuais, os fundamentos, no tocante as questões de fato e de direito, e o dispositivo em que o Juiz decidirá a questão que fomentou a lide. A prolação desta é o momento mais aguardado do processo de procedimento comum, pois tem-se a resposta da tutela jurisdicional do Estado, em outras palavras, a sentença "é emitida como prestação do Estado, em virtude da obrigação assumida na relação jurídico-processual (processo), quando a parte ou as partes vierem a juízo, isto é, exercerem a pretensão à tutela jurídica" conforme Pontes de Miranda (1974, p. 395, apud THEODORO JÚNIOR, 2019, p. 745).

Nesse ponto é importante frisar que algumas sentenças estão sujeitas ao trânsito em julgado conforme disposição de múltiplos artigos contidos no Código. Quando uma decisão transitar em jugado é atribuído o efeito da imutabilidade e consequentemente não pode mais ser atingida por recurso (BARROSO, 2018). Tendo em vista ainda que tal fenômeno é denominado pelo livro de processo como coisa julgada, podendo dizer a respeito das imutabilidades materiais ou formais (BRASIL, 2015).

Nos casos em que a sentença condenar o pagamento de quantia ilíquida, ou seja, a quantia que não é ou não está líquida, apurada, comprovada (ILÍQUIDO, In: DICIO, 2018), é necessário que a sentença seja liquidada, conforme disposição do artigo 509 e seguintes do Código de Processo Civil. É preciso compreender que não é propriamente a sentença que será liquidada, e sim a imposição legal que a sentença constituiu, nesse contexto Alexandre Freitas Câmara (p. 307, 2017) considera “a expressão 'liquidação de sentença' é, na verdade, uma elipse. Afinal, não é a sentença, mas a obrigação, que deve ser revestida de liquidez".

Os artigos supracitados que tratam do procedimento de liquidação prescrevem que esta poderá ser realizada mediante requerimento do credor ou do deve-

\footnotetext{
5 Pessoa que relata um fato que viu ou ouviu.

6 Ação ou efeito de ouvir aquilo que está sendo dito sobre uma coisa em específico; audição.
} 
dor, por meio de arbitramento ${ }^{7}$ nos casos em que a sentença o exija, devendo ser acordado entre as partes ou devido à natureza do objeto da liquidação. No arbitramento as partes apresentarão ${ }^{8}$.

O parágrafo segundo do artigo 509 trata dos casos em que o valor dependa apenas de cálculo aritmético, e, logo em seguida, no parágrafo terceiro atribui ao Conselho Nacional de Justiça o encargo de desenvolver e disponibilizar, um programa de atualização financeira (BRASIL, 2015), isso porque nos casos em que se estabeleça o pagamento de quantia em dinheiro, basta atualizar o valor de acordo com os índices legais estabelecidos e aplicar os juros de mora de acordo com cada caso específico:

Assim, por exemplo, se a sentença condenou o réu a pagar ao autor uma certa quantia em dinheiro, com atualização monetária e juros de mora, estabelecendo os termos iniciais de incidência da correção e dos juros, além de fixar o percentual destes, bastará realizar uma operação aritmética para chegar-se ao valor do crédito exequendo. (CÂMARA, p. 307, 2017).

Ademais, o dispositivo final que trata da liquidação estabelece que nada impede a liquidação das sentenças que se encontram em fase recursal, essas serão liquidadas em autos apartados, devendo o liquidante anexar ao pedido as cópias necessárias.

Não há como abordar todas as fases processuais civis sem referência aos recursos. Interpor um recurso significa postular pelo reexame de decisões, de acordo com J Alvim (2018, p. 394) "a palavra recurso provém do latim recursus, que traz a ideia de voltar atrás; daí o emprego dessa palavra para traduzir o ato por meio do qual se pede o reexame da questão ou da causa decidida".

Não somente as partes podem impugnar as decisões judiciais, terceiros prejudicados e o Ministério Público, quando atua como parte ou como fiscal da ordem jurídica, também podem recorrer conforme disposto no artigo 996 do Código de Processo Civil (BRASIL, 2015). Sendo que só há um recurso cabível contra cada decisão.

Caso não haja interposição recursal, ou após o julgamento do recurso interposto, inicia-se a fase de cumprimento da sentença, pois a finalidade do processo sempre será obter um resultado efetivo além da esfera judicial.

\section{EXECUÇÃO EM GERAL}

Após a via de conhecimento comum formalizar o direito obrigacional do credor por meio de uma sentença, o processo iniciará um viés executório, em que irá buscar a satisfação da obrigação entre medidas coercitivas que pretendem alcançar os bens do devedor. Nesta lógica, preceitua o Código Processual:

\footnotetext{
7 Julgamento, decisão, avaliação por árbitros ou peritos;

8 iz-se da pessoa que foi designada pelo juiz para opinar sobre assuntos que lhe são submetidos em certa ação jurídica.
} 
Art. 789. “O devedor responde com todos os seus bens presentes e futuros para o cumprimento de suas obrigações, salvo as restrições estabelecidas em lei." (BRASIL, 2015).

A Execução não é promovida somente em razão do cumprimento de sentença, pois ela decorre também da ação de Execução Autônoma, que apesar de sua construção distinta, tem o mesmo objetivo, a satisfação da dívida. Dessa maneira, pode-se afirmar que o Código diz respeito a duas execuções, o cumprimento da sentença e a execução independente utilizando das mesmas medidas para obtenção legal do patrimônio do devedor.

São os artigos 513 ao 538 do Título II, do Livro I da Parte Especial do Código que regem a fase de cumprimento de sentença. O parágrafo primeiro do artigo 513 orienta que o interessado no cumprimento da sentença é quem deve requerer no processo. Após o requerimento da parte vencedora ocorre a intimação da parte vencida para realizar a prestação, em prazo determinado pela lei ou fixado pelo juiz, salientando que existem espécies diferentes de cumprimento de sentença.

Conforme preceitua o artigo 516, o cumprimento da sentença deve ser ingressado perante os tribunais originários em que ocorreu o processo de conhecimento ou o juíz decidir a causa em primeiro grau de jurisdição.

Além da fase de cumprimento se iniciar por meio de iniciativa da parte exequente, existem outras regras gerais que conduzem todas as espécies de cumprimento de sentença, Theodoro Júnior $(2019$, p. 1683) indica que "para passar à execução do comando sentencial é indispensável que a condenação corresponda a uma obrigação certa, líquida e exigível". Ou seja, não deverá haver dúvidas quanto à obrigação da sentença prolatada, mas deverá estar apurado o valor condenatório e, ainda, não será passível de termo ou condição.

Deve-se considerar a peculiaridade de cada procedimento de cumprimento de sentença, atentando-se para os tipos de obrigação, destaca-se aqui a obrigação de pagar quantia certa (artigos 523 e seguintes do Código).

Neste instante processual já está ultrapassado todo o processo de conhecimento e em decorrência da coisa julgada o mérito processual não é mais passível de discussão, nessa fase executa-se o título judicial obtido pela parte vencedora, o rol dos títulos executivos judiciais está nos nove incisos artigo 515 do Código de Processo Civil.

Após o capítulo das disposições gerais do Cumprimento de Sentença, o Código trata do Cumprimento Provisório da Sentença que reconhece a exigibilidade da obrigação de pagar quantia certa, provisório porque são sentenças e decisões contra as quais houve interposição de recurso, que não possua o efeito suspensivo.

Ou seja, ainda que a decisão ou sentença elencada no artigo 515 esteja sendo analisada em fase recursal, é possível iniciar a fase de cumprimento de sentença provisoriamente, contanto que o recurso interposto apresente efeito devolutivo e não suspensivo (BRASIL, 2015).

Em seguida, o Código ainda trata do Cumprimento de Sentença que reconhece a exigibilidade da obrigação de pagar quantia certa, entretanto do cumprimento 
definitivo, isto é, neste caso já houve o trânsito em julgado da sentença ou decisão, não sendo mais possível modicar por meio de recurso (BRASIL, 2015).

O pagamento de quantia certa pode estar atribuído a uma dívida comum, decorrente das relações sociais ou a qualquer obrigação de natureza econômica, inclusive judicial:

Obrigação por quantia certa é aquela que se cumpre por meio de dação de uma soma de dinheiro. O débito pode provir de obrigação originariamente contraída em torno de dívida de dinheiro (v.g., um mútuo, uma compra e venda, em relação ao preço da coisa, uma locação, em relação ao aluguel, uma prestação de serviço, no tocante à remuneração convencionada etc.); ou pode resultar da conversão de obrigação de outra natureza no equivalente econômico (indenização por descumprimento de obrigação de entrega de coisa, ou de prestação de fato, reparação de ato ilícito etc.) (THEODORO JÚNIOR, 2017, p. 161).

Todas as fases processuais estão sujeitas ao princípio do contraditório e ampla defesa, por isso, após o transcurso do prazo do pagamento voluntário da obrigação o executado poderá impugnar o cumprimento de sentença em quinze dias, nos mesmos autos do cumprimento, conforme disposição do artigo 525 do Código em consonância com o artigo 518 que trata das disposições gerais.

As questões que podem ser arguidas pelo devedor da obrigação constam no parágrafo primeiro do artigo 525, sendo elas: a falta ou nulidade da citação quando ocorrida a revelida; ser parte ilegítima no cumprimento; o título ou a obrigação serem inexigíveis; ocorrência de erro na penhora ou avaliação, excesso ou cumulação de execução; incompetência absoluta ou relativa do juízo ou ainda, qualquer causa modificativa ou extintiva da obrigação.

Nota-se, portanto, que o devedor não precisa ingressar com nova ação, nem interpor recurso específico para alegar as possíveis ilegalidades, erros e nulidades que podem ocorrer no cumprimento da sentença.

O cumprimento de sentença é uma etapa satisfativa, executória, inserta na ação de procedimento comum e, assim como em todas as fases, não pode deixar de contemplar os princípios processuais concernentes de cada ato.

O processo de execução é regulamentado pelo Livro II da Parte Especial do Código de Processo Civil. O primeiro Título trata das Execuções sob os aspectos gerais e logo nos primeiros artigos são tratadas as medidas judiciais de que o juiz pode se valer a fim de evitar ato atentatório à dignidade de justiça.

Além da legitimidade, inerente a qualquer processo, os requisitos da ação de execução compreendem um credor e um devedor, que fazem a vez das partes, o Estado-Juiz, investido de Jurisdição, o título exequível, e os bens do devedor, até porque sem eles não se prosseguirá com a Execução, sendo que a hipótese de suspensão por inexistência de bens do devedor está no inciso terceiro do artigo 921 do Código Processual. É possível ainda, conforme regimento do artigo 775, que o exequente desista da execução ou de apenas uma medida executiva. 
Passaremos agora a discorrer acerca das Ações de Execuções Autônomas de forma específica, atentando-se que, ambos, o cumprimente de sentença e a ação de execução, visam a satisfação da obrigação imposta ao executado, ou seja, executam um título, por meio dos trâmites legais. A finalidade executória é a mesma nos dois casos.

Nas execuções autônomas basta ingressar no Judiciário com um título executivo extrajudicial e sintetizar o dispositivo 781 do Código de Processo Civil para ingressar no juízo do foro de domicílio do executado e em se tratando de mais de um domicilio, a demanda pode ser ingressada no foro de qualquer um deles; no caso de incerto ou desconhecido, no local onde o executado seja encontrado ou no próprio domicilio do exequente; ou no foro eleito que conste no título; no foro que estejam os bens que dizem respeito a execução ou até mesmo no local em que se originou o título (BRASIL, 2015).

São muitos os títulos executivos extrajudiciais e alguns estão relacionados no artigo 784 do Código, a exemplificar, os documentos particulares assinado pelo devedor e por duas testemunhas, os contratos de seguro de vida e os cheques e também se verifica que no último inciso do referido artigo, estende-se a atribuição de título executivo extrajudiciais a todos os títulos em que a lei atribuir força executória.

Mesmo estando em posse do título executivo extrajudicial é possível ingressar no Judiciário, percorrer todas as etapas do procedimento comum e obter o título executivo judicial, conforme disposição do artigo 785 do Código, ainda que este não seja o caminho mais rápido.

Os títulos executivos extrajudiciais devem estar revestidos de certeza, liquidez e exigibilidade observando o artigo 786, sendo imprescindível não haver qualquer dúvida acerca do quantum debeatur ${ }^{9}$ dos títulos extrajudiciais aos quais o Código não atribui fase de liquidação, dando enfoque aos que preceituam pagar quantia certa.

Nas espécies de execução fundadas em títulos extrajudiciais não se depara com a modalidade provisória, refletindo que esses são documentos os quais não podem ser modificados, como no caso das decisões judiciais em sede recursal.

Diferentemente da impugnação no cumprimento de sentença, a defesa na execução de títulos extrajudiciais é exercida por meio de Embargos à Execução, tratada nos artigos 914 a 920 do Código. Percebe-se que estes embargos têm natureza de ação autônoma, assim entende Alvim (2018, p. 448) "ação pela qual o executado formula uma pretensão consistente na desconstituição do título executivo". Dessa maneira, a impugnação feita à execução dos títulos extrajudiciais não se trata de apenas simples defesa ou recurso processual, mas sim, por apresentar natureza própria seguindo as especificidades de uma petição inicial e podendo o executado alegar qualquer matéria que lhe seria lícita em processo de conhecimento, vide artigo 917.

Constata-se ser necessária a possibilidade que o inciso do artigo supramencionado oferece, pois o procedimento comum de conhecimento delega mais garantias de defesa à parte requerida do processo.

\footnotetext{
9 Quantidade determinada, proporção de uma grandeza em uma divisão, um conjunto. fonte
} 
Logo, os Embargos à Execução são mecanismos legais que objetivam sanar qualquer restrição que o Executado apresente pelo fato de a ação de Execução não conferir as mesmas possibilidades de defesa que o procedimento comum oferece anteriormente ao início da execução.

Sem prejuízo de todas as incumbências e requisitos para interpor os Embargos à Execução, o último artigo que trata da questão prevê que, recebidos os embargos, coerentemente, será ouvido o Exequente, e, caso não for proferido julgamento naquele momento será designada audiência em observância ao artigo 920.

É importante a compreensão do artigo 805, pois atribui à Execução o modo menos gravoso, ou seja, quando puder realizar-se por diversos meios a execução se fará pelo menos gravoso, Montenegro Filho (2018, p. 605) entende que "o dispositivo revela a preocupação do legislador de garantir que a execução não acarrete a ruína financeira e/ou patrimonial do devedor (por razões políticas e sociais)".

Em outro prisma, verifica-se que o Princípio do ônus da execução tem o propósito de esclarecer que o executado deve arcar não somente com a obrigação principal, mas também com todas as outras custas que o credor teve com a execução, este Princípio até mesmo está em consonância com outros regimentos legais civis:

Volta-se, destarte, a execução forçada sempre contra um devedor em
mora; e a obrigação do devedor moroso é a de suportar todas as con-
sequências do retardamento da prestação, de sorte que só se libertará
do vínculo obrigacional se reparar, além da dívida principal, todos os
prejuízos que a mora houver acarretado para o credor, compreendidos
nestes os juros, a atualização monetária e os honorários de advogado
(CC de 2002, arts. 395 e 401) [...] (THEODORO JÚNIOR, 2017, p. 312).

De qualquer forma a execução em geral, visa satisfazer a obrigação do devedor, por meio de medidas coercitivas e orientadas pelo regimento legal, que fazem valer o cumprimento da obrigação com o patrimônio do executado.

Nos termos do inciso II, do artigo 924 do Código de Processo Civil, a Execução será extinta quando a obrigação for satisfeita, tendo em vista que essa é a finalidade da Execução, reconhecer a obrigação perante o Judiciário e valer-se de providências coercitivas que forçam o adimplemento da obrigação.

Observa-se quanto as providências coercitivas que permitem o Exequente apropriar-se dos bens do Executado dispostas no Código, que apesar de não haver nenhuma disposição legal quanto a uma ordem de percurso das medidas, resta sugestionado como e de que forma ocorrerá a expropriação de bens.

Nada impede que o Executado realize o adimplemento da obrigação depois de citado sobre a ação, em razão do estabelecido no artigo 827, podendo até mesmo oferecer seus bens para adimplir e estando sujeito ao aceite do Exequente para isso. Entretanto, especificadamente na Execução Por Quantia Certa, o Código dispõe de medidas que permitem ao Exequente se satisfazer da obrigação, com o patrimônio do Executado e sem sua anuência (BRASIL, 2015). 
Neste liame, acaso o oficial de justiça na tentativa de citar o Executado não o encontre, pode apreender bens a fim de garantir a execução, ato garantido pelo artigo 830.

De qualquer forma, a relação processual se estabelecerá com a citação do Executado, independente do arresto, conforme disposição do artigo em comento. Estabelecida a relação processual, o arresto converter-se-á em penhora, independentemente de termo, o que não impede o Executado de se manifestar no sentido de modificar o bem penhorado desde que submetido às condições contidas na Subseção IV, do Capítulo VI que trata da Execução por quantia certa.

A expropriação de bens na execução é o meio pelo qual o exequente faz valer as medidas executivas para recebimento de seu crédito, coerentemente, dentro dos limites estabelecidos na obrigação imposta por meio do Judiciário.

É essencial observar que mesmo que os títulos judiciais e extrajudiciais sejam objetos totalmente distintos, o Código reassegura as medidas de expropriação e bens do devedor na execução de ambos. Nesse sentido, os atos expropriatórios equivalem ao, de acordo com a professora Gisele Leite (ano e página), "procedimento executivo para pagamento de quantia certa contra devedor solvente, sendo aplicável também à execução fundada em título extrajudicial como também o judicial."

A penhora, como medida coercitiva satisfatória, tem papel fundamental à Execução, pois individualiza e resguarda os bens até o momento de expropriação. A penhora deve englobar o total na obrigação, considerando atualização, juros, custas e honorários, em observância ao artigo 831.

No ponto de vista do credor, a penhora declara os bens do devedor que exercerão o crédito do credor; e na percepção do devedor, a penhora é a perda da posse de bens, por meio de medida forçada (THEODORO JÚNIOR, 2017).

O Código trata não somente da formalização da penhora, mas também de seu objeto, atentando-se ainda para os bens que não são passíveis de penhora. Com isso, o Código intencionou, segundo Theodoro Júnior (2017, p. 5755) "preservar as receitas alimentares do devedor e de sua família". Sem prejuízo disso, o parágrafo primeiro do artigo 833 assegura que a impenhorabilidade não é aplicada à execução de dívida relativa ao bem que a originou, ainda que essa dívida seja contraída para a aquisição do bem. Os bens salvaguardados da penhora constam no rol do artigo 833 .

Ainda em relação ao objeto da penhora, o legislador preocupou-se em estabelecer uma ordem de preferência de bens, conforme disposição do artigo 835, todavia, considerando as peculiaridades de cada caso.

Após a penhora e cumprido as normas de segurança instituídas sob critérios do Conselho Nacional de Justiça, nos termos do artigo 837 e seguintes do Código, será realizada o registro do bem penhorado e o depósito judicial do mesmo, considerando que o Livro Processual Civil regulamenta cada tipo penhora como o lugar e formas de avaliação do bem.

Neste momento, o patrimônio em questão não é mais disponível ao executado e a efetiva satisfação da obrigação, ou seja, transferência de bens, ocorrerá por meio da adjudicação ou alienação do bem:

1. Adjudicação transferência do bem do patrimônio do executado para o 
patrimônio do exequente pelo valor avaliado; 2 . Alienação por iniciativa particular - não havendo interesse por parte do credor em ficar com o bem, mas indica um interessado em comprar o bem, de acordo com o valor avaliado em juízo; 3. Alienação em Hasta Pública - - não havendo interesse nem por parte do credor, nem de outro. Publica-se em editais os bens que estão sendo vendidos, cujo lance, no $1^{\circ}$ leilão não deve ser inferior ao valor de avaliação; no $2^{\circ}$ leilão por qualquer valor desde que não caracterize preço vil (abaixo de $50 \%$ da avaliação). Se o imóvel for arrematado no leilão em pagamento parcelado, este será hipotecado (LEITE, 2018, p. [5]).

Assim, será feita a entrega dos bens depositados em juízo ao Exequente, conforme expedição de mandado de levantamento, após autorizado pelo Juiz, o referido mandado pode ser substituído por transferência eletrônica da quantia para conta bancária vinculada ao juízo e, finalmente, para outra bancária indicada pelo exequente, de acordo com o conteúdo do parágrafo único do artigo 906.

\section{ANÁLISE DO PARCELAMENTO DA DÍVIDA EXEQUENDA EM SEDE DE CUMPRIMENTO DE SENTENÇA}

Sem prejuízo das medidas de expropriação de bens do devedor, o Código de Processo Civil disponibiliza ao devedor executado um mecanismo utilizado assiduamente nas relações de compra e venda do cotidiano social, o parcelamento da dívida exequenda, que está previsto pelo artigo 916, in verbis:

Art. 916. No prazo para embargos, reconhecendo o crédito do exequente e comprovando o depósito de trinta por cento do valor em execução, acrescido de custas e de honorários de advogado, o executado poderá requerer que lhe seja permitido pagar o restante em até 6 (seis) parcelas mensais, acrescidas de correção monetária e de juros de um por cento ao mês.

$\S 1^{\circ} \mathrm{O}$ exequente será intimado para manifestar-se sobre o preenchimento dos pressupostos do caput, e o juiz decidirá o requerimento em 5 (cinco) dias.

$\S 2^{\circ}$ Enquanto não apreciado o requerimento, o executado terá de depositar as parcelas vincendas, facultado ao exequente seu levantamento.

$\S 3^{\circ}$ Deferida a proposta, o exequente levantará a quantia depositada, e serão suspensos os atos executivos.

$\S 4^{\circ}$ Indeferida a proposta, seguir-se-ão os atos executivos, mantido o depósito, que será convertido em penhora.

$\S 5^{\circ} \mathrm{O}$ não pagamento de qualquer das prestações acarretará cumulativamente:

I - o vencimento das prestações subsequentes e o prosseguimento do processo, com o imediato reinício dos atos executivos;

II - a imposição ao executado de multa de dez por cento sobre o valor das prestações não pagas.

$\S 6^{\circ}$ A opção pelo parcelamento de que trata este artigo importa renúncia 
ao direito de opor embargos

$\S 7^{\circ} \mathrm{O}$ disposto neste artigo não se aplica ao cumprimento da sentença. (BRASIL, 2015).

Examinando o artigo em comento, verifica-se que o exequente será intimado para constatar se todos os requisitos inerentes ao parcelamento estão preenchidos, ao passo que o juiz decidirá sobre o requerimento em cinco dias. Enquanto não se decide o requerimento, o executado realizará o depósito das parcelas vincendas, e o exequente poderá requerer o levantamento destas; no caso de deferimento do requerimento o exequente levantará a quantia depositada e os autos serão suspensos em obediência ao artigo 921 , inciso $\mathrm{V}$, que trata da suspensão do processo de execução; no caso de indeferimento do requerimento a execução seguirá com as medidas coercitivas, hipótese que mantém o depósito inicial objetivando sua conversão em penhora.

Verifica-se ainda na leitura do dispositivo 916 que o não pagamento de quaisquer parcelas acarreta o prosseguimento da ação da execução e medidas executórias com o vencimento das parcelas subsequentes, considerando multa de dez por cento do valor remanescente não pago.

É muito importante atentar-se à integralidade do artigo compreendido, pois o parágrafo sexto preconiza que ao optar pelo parcelamento, o executado renunciará ao direito de interpor Embargos à Execução e consequentemente não poderá impugnar as questões que este permite.

Destaca-se o fato de a benesse da autorização do parcelamento legal não poder ser concedida à execução de títulos judiciais, conforme determinação do parágrafo sétimo do artigo estudado.

É possível verificar que o instituto do parcelamento está atrelado aos princípios substanciais que orientam o Processo Civil. De início compreende-se que o parcelamento atribui ao processo uma eficiência mais célere, proveitosa a todos que constam na relação processual, inclusive ao Judiciário. Nesse sentido, parcelar a dívida exequenda nas palavras de Montenegro Filho (2018, p. 678) "permite que a execução seja encerrada em menor espaço de tempo, em proveito não apenas do exequente, como também do Estado-juiz, que se libera do dever de prestar a jurisdição".

Se tratando da celeridade processual o parcelamento é benéfico a ambas as partes do processo, Executado e Exequente, o primeiro se protege das mazelas da expropriação de bens, o segundo resta livre das dificuldades que poderiam ser ocasionadas em razão dos Embargos à Execução e recebe o valor que lhe é de direito em curto espaço de tempo.

O devedor se beneficia com o prazo de espera e com o afastamento dos riscos e custos da expropriação executiva; e o credor, por sua vez, recebe uma parcela do crédito, desde logo, e fica livre dos percalços dos embargos do executado. De mais a mais, a espera é pequena - apenas seis meses, no máximo, um prazo que não seria suficiente para solucionar os eventuais embargos do executado e chegar, normalmente, à expropriação dos bens penhorados e à efetiva satisfação do crédito ajuizado (THEODORO JÚNIOR, 2017, p. 842). 
Outro ponto relevante que se atribui é que a segregação da dívida assume um modo de execução menos gravoso ao executado, em consonância com o artigo 805 com o Código (BRASIL, 2015), haja vista conceder mais tempo ao executado para adquirir recursos para sanar a dívida.

É muito importante observar que o pagamento por meio do parcelamento da dívida exequenda implica na comprovação de 30\% do valor executório incluindo as custas e os honorários de advogado; e as parcelas observam correção monetária mais juros de um por cento ao mês, restando o Exequente mais que assegurado o qual a obrigação será cumprida como se fosse satisfeita à época do inadimplemento.

Em verdade, a lei é expressa e clara quando proíbe a aplicação do parcelamento ao cumprimento de sentença, nos termos do parágrafo sétimo do artigo 916. Ao indagar o porquê o Código de Processo Civil apresenta um posicionamento restritivo ao parcelamento nas dívidas exequendas oriundas de títulos judiciais, pode-se verificar a fundamentação da doutrina e jurisprudência acerca do tema.

Theodoro Júnior (2017), reiteradamente citado nesta monografia, considera o parcelamento próprio aos títulos extrajudiciais por se mostrar uma opção em relação aos Embargos à Execução, figura que não consta em sede de cumprimento de sentença. Nesse aspecto, não haveria razão da aplicabilidade do parcelamento para estes casos, haja vista todo percurso que o exequente percorreu no processo de conhecimento, seria mais um ônus a este esperar mais seis meses pelo adimplemento:

O parcelamento concebido pelo art. 916 é um incidente típico da execução por quantia certa fundada em título extrajudicial, que se apresenta como uma alternativa aos embargos do executado. Figura dentre os dispositivos que regulam os embargos, ação que nem sequer existe na execução de sentença. Aliás, não teria sentido beneficiar o executado condenado por sentença judicial com novo prazo de espera, quando já se valeu de todas as possibilidades de discussão, recursos e delongas do processo de conhecimento. Seria um novo e pesado ônus para o exequente, que teve de percorrer a longa e penosa via crucis do processo condenatório, ter ainda de suportar mais seis meses para tomar as medidas judiciais executivas contra o executado renitente (THEODORO JÚNIOR, 2017, p. 843).

Amorim (2016) também não encontra significado no parcelamento em cenário de cumprimento de sentença, pela espera de seis meses, além do tempo que se considera a formação do título judicial, assim como entendido por Theodoro Júnior (2017), entretanto, Amorim (2016) reconhece que é licito às partes se comporem pela via extrajudicial, nos mesmos moldes estabelecidos pelo artigo 916 do Código:

O $\S 7^{\circ}$ do art. 916 do Novo CPC é expresso no sentido de não ser cabível a moratória legal no cumprimento de sentença, contrariando jurisprudência do Superior Tribunal de Justiça a respeito do tema. Trata-se de acerto do legislador, seja porque não tem sentido o executado reconhe- 
cer o direito exequendo em execução fundada em sentença, seja porque não se pode obrigar o exequente, depois de todo o tempo despendido para a obtenção do título executivo judicial, a esperar mais seis meses para sua satisfação. De qualquer forma, admissível será um acordo no cumprimento de sentença, nos moldes do art. 916 do Novo CPC, ao menos no tocante às condições de pagamento, mas nesse caso não haverá uma moratória legal, mas uma mera transação a respeito da forma de pagamento da dívida (2016, p. 2077 e 2078).

Importante destacar que no ano de 2012 não havia a referida vedação, pois o Código de Processo Civil anterior era omisso quanto ao parcelamento em sede de cumprimento de sentença, porém, um entendimento traçado pelo Superior Tribunal de Justiça pacificou à época a aplicação do parcelamento para os títulos judiciais, conforme a ementa do acórdão reproduzida:

PROCESSO CIVIL. RECURSO ESPECIAL. CUMPRIMENTO DE SENTENÇA. PARCELAMENTO DO VALOR EXEQUENDO. APLICAÇÃO DO ART. 745-A DO CPC. POSSIBILIDADE. PRINCÍPIO DA EFETIVIDADE PROCESSUAL. ART. 475-R DO CPC. APLICAÇÃO SUBSIDIÁRIA. HIPÓTESE DE PAGAMENTO ESPONTÂNEO DO DÉBITO. NÃO INCIDÊNCIA DA MULTA PREVISTA NO ART. 475-J, § 4º, DO CPC. HONORÁRIOS ADVOCATÍCIOS. DESCABIMENTO ANTE O CUMPRIMENTO ESPONTÂNEO DA OBRIGAÇÃO VEICULADA NA SENTENÇA. PRINCÍPIO DA NON REFORMATIO IN PEJUS. VIOLAÇÃO DOS ARTS. 165, 458 E 535 DO CPC NÃO CONFIGURADA.

(STJ - RECURSO ESPECIAL No 1.264.272 - RJ (2010/0039413-9) -- Data do julgamento: 15/05/2012 - Relator (a): Ministro Luis Felipe Salomão - $4^{\mathrm{a}}$ Turma - Voto Unânime)

Atualmente, os tribunais estaduais, em sua maioria, vedam o pleito do parcelamento em discussão, fundamentando-se na literalidade do texto da lei. A exemplificar o julgado abaixo, que recomenda ainda a cooperação entre as partes ante a cenário econômico desfavorável:

CUMPRIMENTO DE SENTENÇA - Indenização - Pedido de parcelamento do débito - Descabimento, por se tratar de cumprimento de título judicial - Vedação expressa do $\$ 7^{\circ}$, do artigo 916, do CPC - Situação atual decorrente da pandemia de coronavírus que, por si, não autoriza a moratória ou o parcelamento da dívida, recomendando, no entanto, a compreensão e a boa vontade dos litigantes com fim à célere satisfação do crédito em proveito de ambas as partes - Recurso desprovido.

(TJ - SP Agravo de Instrumento n ${ }^{\circ}$ 2083995-76.2020.8.26.0000 - Data da publicação: 12/05/2020 - Data do julgamento: 08/05/2020 - Relator (a): Galdino Toledo Júnior - Comarca: Araraquara - Órgão julgador: $9^{a}$ Câmara Cível).

Sem descartar todo estudo acerca da interpretação das normas, mormente o Processo Civil, nota-se das doutrinas e jurisprudências uma interpretação cate- 
górica do texto lei discutido que se amparam, ainda, nos princípios basilares processuais civis, nesse sentido, Theodoro Júnior (2019, p. 90) menciona que, “a fiel interpretação das normas processuais deverá, portanto, ser encontrada à luz dos princípios informativos que estruturam o processo em sua missão específica dentro da ciência jurídica".

É nessa mesma visão e a fim de não excluir os princípios do processo civil, que se fez presente a indagação inicial deste tópico, pretendendo analisar a inaplicabilidade do parcelamento à dívida exequenda originária dos títulos judiciais.

A análise de doutrina e jurisprudência favoráveis a aplicabilidade do parcelamento em questão contempla uma acepção da norma de forma mais ampla, permitindo a inclusão de maior quantidade de princípios processuais civis.

Montenegro Filho (2018) antipatiza com a lei que restringe o parcelamento da dívida ao cumprimento de sentença, justamente por atribuir a celeridade e razoável duração do processo à técnica de parcelamento:

A lei processual optou por não estender a técnica para a fase de cumprimento da sentença, retirando do devedor o direito de formular o pedido quando instado a adimplir a obrigação de pagar soma em dinheiro, com base em título executivo judicial. Antipatizamos com a vedação legal, por entendermos que a possibilidade de parcelamento da dívida contribui para eliminar a controvérsia em espaço de tempo menor (MONTENEGRO FILHO, 2018, p. 678).

Hartmann (2015) critica a referida vedação legal ponderando também a questão da economia processual atribuída ao mecanismo do parcelamento, nestas palavras:

O sétimo parágrafo traz conteúdo criticável, ao não permitir que este parcelamento seja aplicado ao cumprimento de sentença. É curioso que o CPC a todo tempo tenta estimular uma solução, mas aqui cria justamente um obstáculo ao cumprimento da obrigação, o que provavelmente seria até mais rápido do que pela continuidade da execução. A jurisprudência era bem acirrada quanto a esta questão (HARTMANN, 2015, p. 663).

De fato, assim como demonstrado pelo do Tribunal do no Estado de São Paulo, a maioria dos Tribunais Estaduais não consentem com o parcelamento por meio do cumprimento de sentença em razão da vedação legal, porém, ocorre ainda, mesmo sua minoridade, o acatamento do pleito de parcelamento.

Nesses casos, os magistrados valem-se da interpretação extensiva da lei e decidem pelo deferimento do parcelamento pleiteado pelo exequente nas dívidas originárias de títulos executivos judiciais. A exemplificar o julgado a seguir do Tribunal de Justiça do Estado do Paraná, que além de estimar os princípios da razoável duração do processo e menor onerosidade, constata a presença de inconstitucionalidade em razão da vedação ao parcelamento contrapor os princípios da igualdade e da dignidade do devedor: 
AGRAVO DE INSTRUMENTO - LOCAÇÃO - CUMPRIMENTO DE SENTENÇA EM AÇÃO DE COBRANÇA - DECISÃO RECORRIDA QUE INDEFERIU PEDIDO DE PARCELAMENTO DO DÉBITO - ALEGAÇÃO DE POSSIBILIDADE DESSA OCORRÊNCIA, EM RAZÃO DOS TERMOS DO ARTIGO 916 DO CPC, ALÉM DE APLICABILIDADE DOS PRINCÍPIOS DA COOPERAÇÃO E DA RAZOÁVEL DURAÇÃO DO PROCESSO, ENSEJANDO INCIDÊNCIA NO CUMPRIMENTO DE SENTENÇA -- CONSTATAÇÃO - EXISTÊNCIA DE INCONSTITUCIONALIDADE DO $\S 7^{\circ}$ DO ARTIGO 916 DO CPC POR VIOLAÇÃO AOS PRINCÍPIOS DA IGUALDADE E DA DIGNIDADE DO DEVEDOR, ALÉM DA VEDAÇÃO SER CONTRÁRIA AOS PRINCÍPIOS DA RAZOABILIDADE, DA MENOR ONEROSIDADE E DA RELATIVA DURAÇÃO DO PROCESSO - AFASTAMENTO DA VEDAÇÃO QUE ENSEJA A POSSIBILIDADE DE APLICABILIDADE DO PARCELAMENTO AO CUMPRIMENTO DE SENTENÇA - PRECEDENTES DESTA CORTE - DECISÃO REFORMADA. RECURSO CONHECIDO E PROVIDO. 1. É possível a aplicabilidade da regra do parcelamento ao cumprimento de sentença, uma vez que a vedação posta no $\S 7^{\circ}$ do artigo 916 do CPC violaria os princípios da razoável duração do processo, da igualdade e da dignidade do devedor, além de ser contraproducente, inobservando a razoabilidade e o da menor onerosidade.2. No caso, defere-se o pedido de parcelamento do débito ao executado, por ter havido o depósito da entrada, além das consequentes parcelas mensais consecutivas aos autos originários. (TJ - PR Agravo de Instrumento $\mathrm{n}^{\circ}$ 0040465-69.2019.8.16.0000 - Data da publicação: 12/12/2019 - Data do julgamento: 10/12/2019 - Relator (a): Roberto Antônio Massaro - Comarca: Londrina - Órgão julgador: $12^{a}$ Câmara Cível).

Mais um julgado demonstra, de forma semelhante, que outro juiz do Estado do Paraná não viu óbice em consentir com o parcelamento em razão ao princípio da cooperação processual, observando que estava decidindo de acordo interpretação mais ampla da lei:

AGRAVO DE INSTRUMENTO. AÇÃO DE INDENIZAÇÃO. Cumprimento de sentença. Nova sistemática estabelecida pelo CPC (Lei $\mathrm{n}^{\circ}$ 13.105/2015). Parcelamento do débito, com depósito inicial de 30\%, com amparo no art. 916, do CPC/2015. Concordância do credor. Decisão que determinou a realização de depósito do valor remanescente, acrescido de multa e honorários advocatícios de $10 \%$, cada. Necessidade de reforma. Possibilidade de parcelamento em sede de cumprimento de sentença mediante concordância expressa do credor. Princípio da cooperação processual. Não cabimento de multa e honorários. Interpretação extensiva do art. 916, $\S 7^{\circ}, \mathrm{CPC} / 2015$. Decisão reformada. Recurso provido. (TJ - PR Agravo de Instrumento $n^{\circ} 1641807-8$ - Data da publicação: 22/05/2017 - Data do julgamento: 09.05.2017 - Relator (a): Ruy Cunha Sobrinho - Comarca: Londrina - Órgão julgador: $1^{\text {a }}$ Câmara Cível).

Além dos doutrinadores e do Judiciário não compactuarem com referida vedação legal, o deputado federal Welington Coimbra, apresentou à Câmara Legisla- 
tiva o projeto de lei de $n^{\circ} 8394$ /2017, objetivando a revogação do parágrafo sétimo do artigo 916 do Código de Processo Civil e o parcelamento da sentença exequenda. A justificação do referido projeto, que se encontra arquivado, tem embasamento na preocupação com o devedor que não possui condições de arcar com a dívida de imediato e em razão disso prejudica-se a celeridade processual (COIMBRA, 2017, p. [1 e 2]).

O exposto retrata dois cenários distintos: no primeiro, defende-se a aplicação taxativa da lei; são uniformes os entendimentos que consideram desnecessária a prática do parcelamento no sentido de considerar que o processo de conhecimento comum é, logo, o suficiente, por isso não seria correto estender a conclusão da satisfação por mais tempo. O ponto de vista adverso é construído por meio dos princípios processuais civis, fundamentando-se neles, objetivam viabilizar a técnica do parcelamento a todas as dívidas exequendas, inclusive, ainda que de forma minoritária, a aplicação do parcelamento tratada do artigo 916, nos casos de execução de título judicial se faz presente por meio da permissão de poucos magistrados.

\section{CONSIDERAÇÕES FINAIS}

Não há como traçar comparações entre os títulos executivos judiciais e extrajudiciais, são completamente distintos. O primeiro forma-se por meio do procedimento comum, que a depender de cada caso concreto, pode levar um grande espaço de tempo entre as fases do processo; o segundo é obtido fora da esfera judicial e sua execução é imediata.

De forma congruente, a execução de cada título dispõe de impugnações diferentes, entretanto, o Código atribui as mesmas medidas expropriatórias para as execuções dos dois títulos e somente exime o mecanismo do parcelamento dos judiciais.

Em que pese todo entendimento do legislador, doutrinadores e juristas que acordam em excluir o parcelamento da dívida exequenda originária do cumprimento de sentença, argumentando no sentido de que a lei é expressa e não seria vantajoso ao exequente aguardar por mais possíveis seis meses para adimplemento total da dívida, a abordagem da lei mais ampliativa acompanha maior quantidade de princípios processuais civis.

A argumentação que confere ao parcelamento uma medida penosa em razão do tempo que perduram as ações ordinárias não leva em consideração a relatividade, ou seja, a peculiaridade de cada caso, basta verificar os aspectos gerais do percurso processual civil para perceber que não se pode afirmar que todo processo se estenderá por anos. Entretanto, sabe-se que uma das etapas mais duradouras é a expropriação de bens, pois a penhora, a adjudicação e o leilão, não dependem somente de que o devedor cumpra os requisitos legais, como no caso do parcelamento a expropriação é mais desgastante ao credor e vagarosa ao Judiciário.

Nesse sentido, verifica-se que para o executado parcelar sua obrigação é necessário o preenchimento de todos os requisitos estabelecidos em lei, não se trata de um mecanismo arbitrário, mas que se baseia na cooperação entre as partes para a satisfação ocorrer de forma célere e proveitosa a ambos. 
De qualquer forma, no ponto de vista prático da atuação do Judiciário, tenha o magistrado uma visão categórica da lei, ou não, não há óbice legal que impeça a composição das partes extrajudicialmente, precisamente nos termos do artigo 916 do Código de Processo Civil, o que pode vir a ser uma circunstância favorável à aplicabilidade discutida, pois se há possibilidade de concretização da prática extrajudicialmente não há razão para o entrave no Judiciário que impeça as partes de satisfazerem a obrigação por este modo quando não houver possibilidade de compor além do processo.

Conforme constatado, por meio dos entendimentos jurisprudenciais, mesmo que seja algo vedado expressamente pela lei, e, mesmo que a doutrina pondere não haver sequer o que se falar acerca do pagamento parcelado nas execuções de títulos judiciais, a prática segue sendo postulada no judiciário e deferida pelos magistrados.

Pelo exposto, a aplicação do parcelamento de dívida exequenda que teve sua origem em cumprimento de sentença, mostra-se como uma ferramenta útil à satisfação das dívidas judiciais.

\section{REFERENCIAS}

ALVIM, José Eduardo Carreira. Teoria geral do processo. 21. ed. rev. e atual. - Rio de Janeiro, Forense, 2018.

BARROSO, Carlos Eduardo Ferraz de Mattos. Processo civil: teoria geral do processo e processo de conhecimento, 16. ed. São Paulo: Saraiva Educação, 2018. (Coleção sinopses jurídicas; v. 11).

BRASIL, Constituição (1988). Constituição da República Federativa do Brasil. Brasília, DF: Senado Federal. Disponível em: http://www.planalto.gov.br/ccivil_03/constituicao/ constituicao.htm . Acesso em: 4 de abr. 2020. Texto Original.

BRASIL, Código de Processo Civil (2015). Brasília, DF: Senado Federal. Disponível em: http://www.planalto.gov.br/ccivil_03/_ato2015-2018/2015/lei/113105.htm . Acesso em: 4 de abr. 2020. Texto Original.

BRASIL, Superior Tribunal de Justiça. (RECURSO ESPECIAL No 1.264 .272 - RJ (2010/0039413-9) - Data do julgamento: 15/05/2012 - Relator (a): Ministro Luis Felipe Salomão - $4^{\mathrm{a}}$ Turma - Voto Unânime).

CÂMARA, Alexandre Freitas. O novo processo civil brasileiro. $3^{\text {a }}$ Ed. São Paulo, Atlas, 2017.

COIMBRA, Lelo. Assembleia Legislativa, Projeto de Lei 8394/17, Permite o parcelamento de sentença exequenda. Disponível em: https://www.camara.leg.br/proposicoesWeb/ prop_mostrarintegra;jsessionid=61E74745A1DC23BE9610245CADAFEF0A.proposicoesWebExterno2?codteor=1591349\&filename=PL+8394/2017. Acesso em: 30 out. 2019.

DICIO, Dicionário Online de Português. Porto: 7Graus, 2019. Disponível em: <https:// www.dicio.com.br/>. Acesso em: 11 de abr. 2020. 
HARTMANN, Rodolfo Kronemberg. Novo código de processo Civil Comparado e Anotado. $1^{\text {a }}$ Ed. Rio de Janeiro, Impetus, 2015.

LEITE, Gisele. Expropriação dos bens do executado, 2018. Disponível em: https:/ / www. jornaljurid.com.br/colunas/gisele-leite/expropriacao-dos-bens-do-executado. Acesso em: 14 de mar. 2020.

MONTENEGRO FILHO, Misael. Novo código de processo Civil Comentado. 3 . $^{\mathrm{a}}$ Ed. São Paulo: Atlas, 2018.

NEVES, Daniel Amorim Assumpção. Manual de direito processual civil - Volume único. 8 Ed. Salvador: JusPodivm, 2016.

PARANÁ. Tribunal de Justiça. (Agravo de Instrumento n ${ }^{\circ}$ 1641807-8 - Data da publicação: 22/05/2017 - Data do julgamento: 09.05.2017 - Relator (a): Ruy Cunha Sobrinho - Comarca: Londrina - Órgão julgador: $1^{\mathrm{a}}$ Câmara Cível).

PARANÁ. Tribunal de Justiça. (Agravo de Instrumento no 0040465-69.2019.8.16.0000 - Data da publicação: 12/12/2019 - Data do julgamento: 10/12/2019 - Relator (a): Desembargador Roberto Antônio Massaro - Comarca: Londrina - Órgão julgador: $12^{a}$ Câmara Cível).

SÃO PAULO. Tribunal de Justiça. (Agravo de Instrumento n ${ }^{\circ}$ 2083995-76.2020.8.26.0000 Data da publicação: 12/05/2020 - Data do julgamento: 08/05/2020 - Relator (a): Galdino Toledo Júnior - Comarca: Araraquara - Órgão julgador: $9^{a}$ Câmara Cível).

THEODORO JUNIOR, Humberto. Curso de Direito Processual Civil. Vol. I - teoria geral do direito processual civil, processo de conhecimento, procedimento comum, $60^{\mathrm{a}} \mathrm{Ed}$. Rio de Janeiro, Forense, 2019

THEODORO JUNIOR, Humberto. Curso de Direito Processual Civil. Vol. III - Execução forçada: Cumprimento da sentença; Execução dos títulos extrajudiciais; Processos nos tribunais, Recursos, Direito Intertemporal, 50ª Ed. Rio de Janeiro, Forense, 2017

THEODORO JUNIOR, Humberto; et al. Novo CPC - Fundamentos e sistematização, Rio de Janeiro, Forense, 2015

ZANIN, Ana Paula. “Tire suas dúvidas sobre direito civil”, 2019. Disponível em: https:/ / www.aurum.com.br/blog/direito-civil/ . Acesso em: 14 de mar. 2020.

Responsável pela revisão: Giovanna Begotti Domingos 